«Системні технології» 2 (133) 2021 «System technologies»

DOI 10.34185/1562-9945-2-133-2021-04

UDC 621.31

A.S. Tonkoshkur, A.S. Lozovskyi

\title{
APPLICATION FOR CALCULATING THE PARAMETERS OF A GAS SENSOR FROM THE EXPERIMENTAL KINETIC DEPENDENCE OF RESPONSE
}

Abstract. The elements of the structure and user interface of a specialized application for processing experimental data and calculating the parameters of gas sensors, based on the concept of using various software, packages and media are presented that are most effective at each stage. The application provides such service functions as data entry using Excel spreadsheet program; calculations in the mathematical package "Mathcad"; test item examples of using computational algorithms and providing the necessary textual information from internal sources and the Internet.

Key words: gas detector, modeling, software, calculation of parameters, algorithm

Introduction. The processing of experimental data in order to obtain information on the physical and technical properties of gas detectors, in particular, semiconductor sensors, is one of the most important tasks in their research and application. Recently, it show that kinetic characteristics seem to be an effective tool for obtaining information on the parameters of transient processes that determine the features of the electrical conductivity of such sensor materials [1, 2].

One of the promising areas for achieving these goals is the analysis of response kinetics using general phenomenological models based on the stretched exponential Kohlrausch-Williams-Watts function [3-5].

Its feature is its suitability for describing relaxation phenomena in disordered systems, in which dynamic processes occur simultaneously in several time intervals [6].

It will be observed that the solution to this problem is associated with a number of difficulties associated with processing large amounts of data, the need to use complex algorithms to ensure acceptable accuracy of calculations, etc. In this regard, it seems appropriate to computerize such work from the point of view of developing a specialized application solve the given framework of the problem of data process-

(C) Tonkoshkur A.S., Lozovskyi A.S., 2021 
«Системні технологіï» 2 (133) 2021 «System technologies»

ing concepts using various software packages and environments, the most effective at each stage $[1,7]$.

Problem statement. The article presents the elements of the structure and user interface of a specialized application intended for processing experimental kinetic dependences of the response of gas-sensitive sensors and calculating their parameters.

Structure diagram of the application. The application is designed for manage a library of application software modules, which are documents of the wellknown mathematical package Mathcad and an Excel spreadsheet. The general structure and list of modules are represented in Fig. 1.

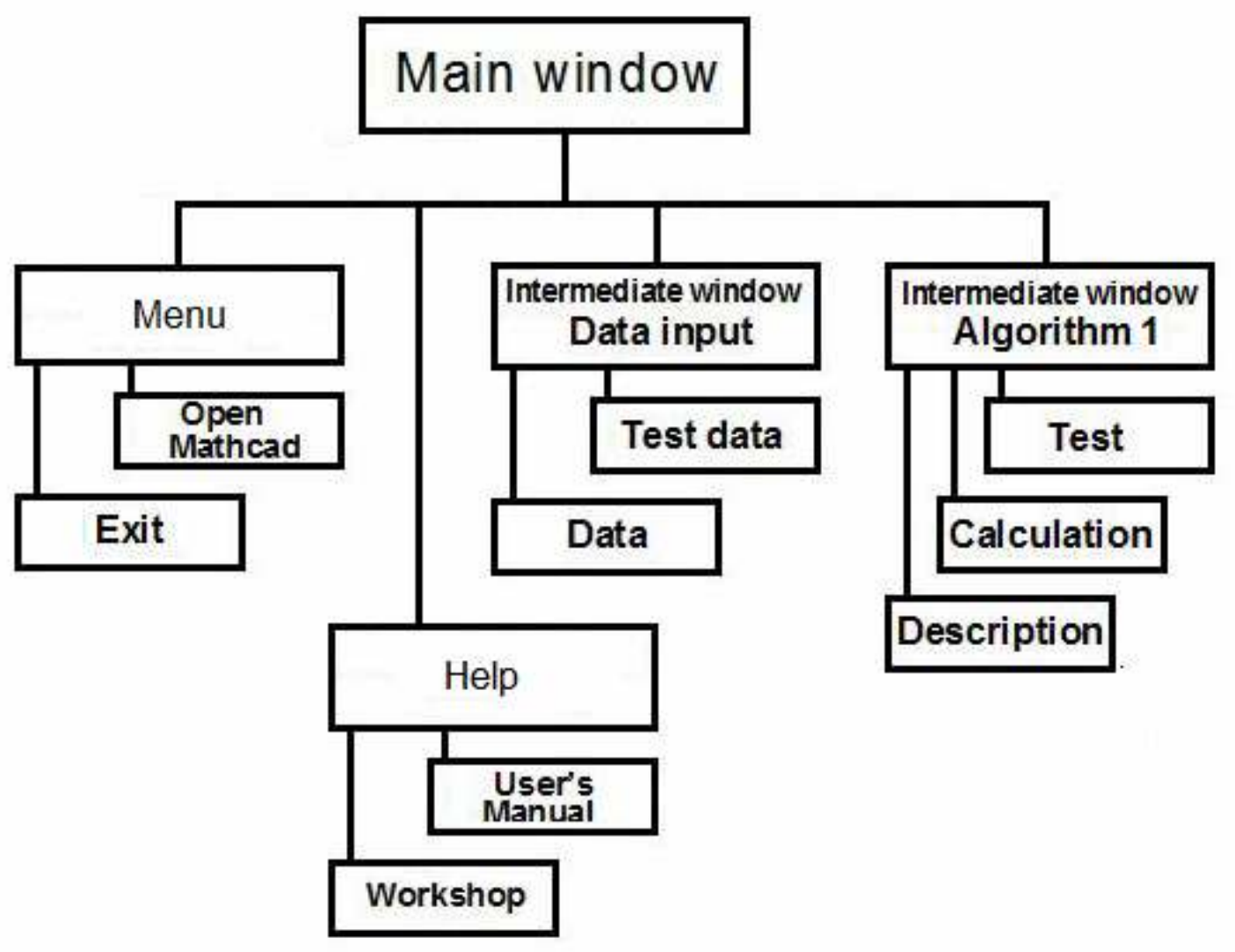

Figure 1 - Block diagram of an application for calculating the parameters of a gas sensor from the experimental kinetic dependence of its response

As you can see, the library consists of the Menu and Help sections and two intermediate windows Data Input and Algorithm 1, containing subsections that correspond to the solutions to the problems of entering experimental data and finding the parameters of the gas sensor under study. 


\section{«Системні технології» 2 (133) 2021 «System technologies»}

The components of the library subsections (Mathcad documents) are represented in two versions: test and open for modification by the user, and contain a description file for the corresponding method.

As additional services, the scheme provides for the possibility of directly calling the mathematical package Mathcad and exiting the program, as well as being acquainted with the user manual and going online to obtain additional literature data.

The main menu of the package links all sections; Mathcad-documents are located in the corresponding sections.

Design of the user interface window. The environment for the operation of the described software product is the Windows operating system. Navigation between sections is carried out using buttons and menus of various levels (main, intermediate and work menus) [8].

The application uses the Monitor, which is written using the $\mathrm{C} \#$ language and the Windows Forms Application project type of the Visual Studio.Net platform. The applied program modules of the library of computational algorithms, as already mentioned, are documents of the well-known mathematical package Mathcad (version 13). In addition, the application uses universal tools for working with files with extensions such as .xls, docx and .pdf.

The main elements of the main window are buttons with inscriptions that indicate the action to be performed when they are pressed (Fig. 1). Pressing the "Input date" button calls an intermediate menu, indicates the layout of the information entered and makes it possible to go to the "Excel" window, which contains the data for testing ("Test") or into which the experimental data intended for processing should be entered ("Data").

The button "Algorithm 1" is designed to go to the intermediate window of the same name. The window contains a brief description of the algorithm and a menu of the following three items, which initialize actions in accordance with the block diagram in Fig. 1:

"Test" call the Mathcad package window with a test case (does not allow any changes);

"Calculation" call the Mathcad package window with a similar file used to process the experimental data loaded for processing;

"Description" of opening a .pdf file with a detailed description of the selected method.

The main window also contains a toolbar with two buttons "Menu" and "Help". The Menu button contains two items. When you select the first of them, "Open 28 


\section{«Системні технологіï» 2 (133) 2021 «System technologies»}

Mathcad", Mathcad will be launched or the screen will ask you to select the Mathcad launch file yourself. When you select the second item "Exit", the application will be closed. The Help button also contains a two-item menu. The item "User's Manual" opens a document with user instructions. The item "Workshop" launches a browser to access the Internet.

It will be observed that before using the described software product on a specific computer, it is necessary to install it together with the standard mathematical package Mathcad, Excel, a browser and tools for reading files with the .pdf extension. Setting up the product presented here comes down to writing in the Visual Studio environment the corresponding file addresses in its monitor, which contain specific software implementations of computational algorithms from its library.

Algorithms of calculation. The application uses an algorithm for calculating physicochemical parameters from the kinetic dependence of the reaction of its resistance to the presence of an active gas in an air atmosphere, designed in the form of a Mathcad package program, in accordance with the methods described in [1, 2].

The experimental data processing algorithm based on the KohlrauschWilliams-Watts stretched exponential function model includes the following operations:

1. Data entry using the above user interface.

2. Primary data processing:

- Presentation of data in the form of a graph and visual assessment of its correctness;

- Transfer of the time count at the moment when the relaxation (restoration of resistance) of the sensor begins after the removal of the active gas from the air atmosphere;

- Data presentation in double logarithmic coordinates

- Building on their basis empirical (tabular) regression dependence.

3. Finding the value of the unknown coefficient $\beta$

- Representation of an empirical (tabular) regression dependence in the form of an interpolation polynomial using cubic splines;

- Derivative calculations $d \log S(t) / d t$ based on the previously obtained tabular dependence, which was previously represented in the form of an interpolation polynomial;

- Representation of the empirical regression dependence in coordinates $t \times[d \log S(t) / d t]$ and $\log S(t)$; 


\section{«Системні технології» 2 (133) 2021 «System technologies»}

- Visual selection of the area above the specified dependence where the model is applicable (i.e., the dependence becomes straight, and the coefficient $\beta$ is the tangent of its angle) and the calculation of the value $\beta$.

4. Determination of unknown parameters $\tau K W W$ and $S(0)$

- Representation of the empirical regression dependence in coordinates $[-\Delta \ln S(t) / \Delta(t \beta)]-1 / \beta$ and $\log S(t)$;

- Approximation of this dependence by a straight line and calculation of parameters $\tau K W W$ and $S(0)$.

Conclusions. A variant of a specialized application for calculating the parameters of a gas sensor from the experimental kinetic dependence of its response, based on the complex use of dissimilar software products, is presented. The application provides the following service functions:

- data entry using Excel spreadsheet program;

- calculations in the mathematical package "Mathcad" of the specified parameters;

- providing the necessary text information about the used calculation algorithms and test examples of their use;

- Internet access if necessary for additional information.

\section{REFERENCES}

1. Tonkoshkur O.S., Povzlo O. L. Algorithm for processing kinetics data to a resistive gas sensor based on a model of an extended exponential function. System technologies. Regional mizhvuzivskiy collection of science works. - Pub. 1 ' (108) - Dnipropetrovsk, 2017 .-- S. 129-134.

2. Tonkoshkur, A. S., Lyashkov, A. Y., \& Povzlo, E. L. (2018). Kinetics of Response of $\mathrm{ZnO}-\mathrm{Ag}$ Ceramics for Resistive Gas Sensor to the Impact of Me-thane, and its Analysis Using a Stretched Exponential Function. Sensors and Ac-tuators B: Chemical. Vol. 255, Part 2. February, P. 1680-1686. https://doi.org/10.1016/j.snb.2017.08.171.

3. J. Trzmiel, K. Weron, J. Janczura, E. Placzek-Popko, Properties of the relaxationtime distribution underlying the Kohlrausch-Williams-Watts pho-toionizationof the DX centers in Cd1-xMnxTe mixed crystals, J. Phys .: Condens. Matter 21 (34) (2009).

4. J.C. Phillips, Stretched exponential relaxation in molecular and elec-tronicglasses, Rep. Prog. Phys. 59 (9) (1996) 1133-1207.

5. S.I. Simdyankin, N. Mousseau, Relationship between dynamicalhet-erogeneities and stretched exponential relaxation, Phys. Rev. E 68 (4) (2003) (041110).

6. A.V. Milovanov, J.J. Rasmussen, K. Rypdal, Stretched-exponential decayfunctions from a self-consistent model of dielectric relaxation, Phys. Lett. A372 (2008) 21482154. 


\section{«Системні технологіï» 2 (133) 2021 «System technologies»}

7. Tonkoshkur A.S., Karpenko N.V. Architecture and description of the applied programs package for electrical properties simulation of heterogene-ous materials. System technologies. Regional mizhvuzivskiy zbirnik na-ukovykh prats. - Pub. 1 ' (114) Dnipro, 2018. - P. 136-141

8. Programming in Windows Forms: [Electronic resource]. Access mode: https://metanit.com/sharp/windowsforms

\section{ЛІТЕРАТУРА / ЛИТЕРАТУРА}

1. Тонкошкур О.С., Повзло Є.Л. Алгоритм обробки даних кінетики відгуку резистивного газового сенсору на основі моделі розтягнутої експоненціальної функції. Системні технології. Регіональний міжвузівський збірник наукових праць. - Вип. 1'(108) - Дніпропетровськ, 2017. - С. 129-134.

2. Tonkoshkur, A. S., Lyashkov, A. Y., \& Povzlo, E. L. (2018). Kinetics of Response of $\mathrm{ZnO}-\mathrm{Ag}$ Ceramics for Resistive Gas Sensor to the Impact of Methane, and its Analysis Using a Stretched Exponential Function. Sensors and Actuators B: Chemical. Vol. 255, Part 2. February, P. 1680-1686. https://doi.org/10.1016/j.snb.2017.08.171.

3. J. Trzmiel, K. Weron, J. Janczura, E. Placzek-Popko, Properties of the relaxationtime distribution underlying the Kohlrausch-Williams-Watts photoionizationof the DX centers in Cd1-xMnxTe mixed crystals, J. Phys.: Condens. Matter 21(34) (2009).

4. J.C. Phillips, Stretched exponential relaxation in molecular and electronicglasses, Rep. Prog. Phys. 59 (9) (1996) 1133-1207.

5. S.I. Simdyankin, N. Mousseau, Relationship between dynamicalheterogeneities and stretched exponential relaxation, Phys. Rev. E 68 (4)(2003) (041110).

6. A.V. Milovanov, J.J. Rasmussen, K. Rypdal, Stretched-exponential decayfunctions from a self-consistent model of dielectric relaxation, Phys. Lett. A372 (2008) 21482154.

7. Tonkoshkur A.S., Karpenko N.V. Architecture and description of the applied programs package for electrical properties simulation of heterogeneous materials. Системні технології. Регіональний міжвузівський збірник наукових праць. Вип. 1'(114) - Дніпро, , 2018. - С. 136-141

8. Программирование в Windows Forms: [Електронний ресурс]. Режим доступу: https://metanit.com/sharp/windowsforms

Received 08.02.2021. Accepted 09.02.2021.

\section{Додаток для розрахунку параметрів газового сенсора з експериментальної кінетичної залежності його відгуку}

Представлены элементы структуры и пользовательского интерфейса специализированного приложения для обработки экспериментальных данных и расчета параметров газовых сенсоров, основанного на концепции использования различного программного обеспечения, пакетов и носителей, наиболее эффективных на каждом этапе. Приложение предоставляет такие сервисные функции, как ввод данных с помощью программы электронных таблиц Excel; расчеты выполнены в математическом пакете «Mathcad»; 


\section{«Системні технології» 2 (133) 2021 «System technologies»}

примеры тестовых заданий с использованием вычислительных алгоритмов и предоставлением необходимой текстовой информации из внутренних источников и Интернета.

\section{Додаток для розрахунку параметрів газового сенсора}

з експериментальної кінетичної залежності його відгуку

Одним з перспективних напрямків отримання інформації про фізико-технічні характеристики сучасних напівпровідникових матеріалів для газових сенсорів є аналіз кінетики відгуку їх електропровідності з використанням загальних феноменологічних моделей, заснованих на розтягнутій експоненціальній функції Кольрауша-Вільямса-Вотса. Однак його використання стримується низкою труднощів, пов'язаних з обробкою великих масивів даних, необхідністю використання складних алгоритмів для забезпечення прийнятної точності обчислень і так далі. У зв'язку з цим вважається за доцільне комп'ютеризувати процес обробки експериментальних даних шляхом створення відповідної інтелектуальної вимірювальної інформаційної системи.

у даній роботі представлені елементи структури і інтерфейсу спеціалізованого додатку на основі алгоритму моделі розтягнутої експоненціальної функції для обробки даних кінетики відгуку резистивних газових сенсорів. При створенні програми застосована концепція використання різних програмних пакетів і середовищ, найбільш ефективних на кожному етапі обробки і аналізу даних. Додаток надає такі сервісні функції, як введення даних за допомогою електронних таблиць Exсеl; розрахунки в математичному nакеті «Mathcad»; тестові приклади використання обчислювальних алгоритмів і надання необхідної текстової інформації з внутрішніх джерел та Інтернету.

Тонкошкур Олександр Сергійович - професор, д.ф.-м.н., професор кафедри ЕОМ Дніпровського національного університету імені Олеся Гончара.

Лозовський Андрій Сергійович - аспірант кафедри електронних обчислювальних машин факультету фізики, електроніки та комп’ютерних систем Дніпровського національного університету ім. О. Гончара.

Тонкошкур Александр Сергеевич - профессор, д.ф.-м.н., профессор кафедры ЭВМ Днепровского национального университета имени Олеся Гончара.

Лозовский Андрей Сергеевич - аспирант кафедры электронных вычислительных машин факультета физики, электроники и компьютерных систем Днепровского национального университета им. О. Гончара.

Tonkoshkur Alexander Sergeevich - professor, doctor of physical and mathematical sciences, professor at the Department of Electronic Computing Machinery of Oles Honchar Dnipro National Universityю

Lozovsky Andrey Sergeevich - post-graduate student of the department of electronic computers of the faculty of physics electronics and computer systems of the Oles Honchar Dnipro National University. 